\title{
Armas de doble filo. Estrategias y argumentaciones de los abogados representantes de acusados y acusadores en procesos por delitos sexuales. Ciudad de México, 1827-1871
}

\author{
Double-edged weapons. Strategies and arguments of lawyers \\ representing defendants and prosecutors in sex crimes trials. \\ Mexico City, 1827-1871
}

Alejandra Palafox Menegazzi*

\section{RESUMEN}

En este trabajo buscamos evidenciar las principales tendencias Palabras clave: argumentativas adoptadas por abogados -representantes de cultura judicial, acusados y acusadores - en procesos por delitos sexuales, perdelitos sexuales, petrados por mujeres o contra mujeres, que fueron incoados en México, siglo XIX. la ciudad de México entre 1827 y 1871. Para ello, desarrollamos un análisis discursivo de las declaraciones y alegatos contenidos en los expedientes judiciales del fondo documental Tribunal Superior del Distrito Federal del Archivo General de la Nación de México, revisado en su totalidad para este periodo, además de leyes, artículos, diccionarios y tratados de Derecho. En un marco penal anterior a la codificación, caracterizado por un vacío legal y el ejercicio de un amplio arbitrio judicial, perseguimos conocer la relación que los letrados establecieron entre la ley y las circunstancias que rodeaban al delito juzgado. Al respecto, buscamos poner de manifiesto cómo los abogados recurrieron en sus discursos a una serie de estereotipos y prejuicios reproductores y promotores de amplias desigualdades en términos étnicos, de clase y de género, interpretando sus argumentaciones como me-

* Española. Doctora en Historia por la Universidad de Granada, España. Docente, Universidad Autónoma de Chile. E-mail: alejandra.palafox@uautonoma.cl Este trabajo recoge resultados de la investigación financiada por el Programa de Formación del Profesorado Universitario (FPU) del Ministerio de Educación del Gobierno de España, entre 2012 y 2016. 
dios de interacción social y parte de una cultura jurídica compartida.

\section{SUMMARY}

In this work, we seek to evidence the main argumentative tendencies adopted by lawyers - defendants' representatives and accusers - in proceedings for sexual crimes perpetrated by women or against women initiated in Mexico City between 1827

Keywords: judicial culture, sexual crimes, Mexico, 19 th century. and 1871. For this purpose, we developed a discursive analysis of statements and allegations contained in the judicial files of the Federal District Superior Court documented endowment of Mexico's General Archive, reviewed in its entirety for this period, in addition to laws, articles, dictionaries and law treaties. In a criminal framework before the codification, characterized by a legal vacuum and the exercise of broad judicial discretion, we sought to understand the relationship that lawyers established between the law and the circumstances surrounding the crime in question. In this regard, we seek to reveal how the lawyers resorted to a series of stereotypes and prejudices in their speeches -reproducers and promoters of broad ethnic, class, and gender inequalities-, interpreting their arguments as means of social interaction and part of a shared legal culture. 
En el presente artículo buscamos conocer cuáles fueron las principales variables destacadas por los abogados de acusados y acusadores a la hora de formular sus defensas en procesos por delitos sexuales perpetrados por mujeres o contra mujeres entre 1827 y 1871 . Al respecto, buscamos evidenciar cuál fue la relación que estos letrados establecieron en sus discursos entre la ley y las circunstancias que rodeaban al delito juzgado. Para lograr estos objetivos, comenzaremos señalando el complejo marco de pluralismo normativo que reinó en la ciudad de México desde su independencia política y hasta la conclusión del proceso de codificación penal en 1871.

Con la actual categoría de "delitos sexuales" hacemos referencia a un conjunto de comportamientos y uniones que fueron perseguidos y sancionados por las instancias judiciales capitalinas por sobrepasar el legítimo y exclusivo ámbito del matrimonio, y que fueron interpretados, según los principales tratadistas, como abusos de los placeres sensuales (Escriche, 1852) y atentados contra la moralidad pública y el orden de las familias (Dublán, y Méndez, 1870). Englobados por estos juristas dentro de la categoría de "delitos de incontinencia" (Escriche, 1852: 847), empleada ya desde el siglo XVIII (Sánchez, 2013), o de "delitos de sensualidad" (Dublán, y Méndez, 1870: 147), ya en época independiente, los comportamientos reprobados a los que nos referimos se significaron bajo las volubles tipificaciones de adulterio, amancebamiento o concubinato, bigamia, estupro, fuerza, incesto, lenocinio y rapto, y estuvieron formalmente regulados por un complejo conjunto normativo de época colonial y, principalmente, por lo recogido en las leyes de Partidas y la Novísima Recopilación. ${ }^{1}$ La caída en desuso de las severas penas contempladas en estos cuerpos legales, de acuerdo con los principios liberales (que incluían la defensa de la humanización de las condenas y su proporcionalidad con el delito cometido), implicó un vacío legal, suplido durante la práctica judicial por el empleo continuado de diccionarios y tratados de Derecho, así como por el ejercicio de un amplio arbitrio en la resolución de los procesos (Speckman, 2007: 189-206).

Explicaremos en qué consistían cada una de estas tipificaciones a medida que hagamos referencia a ellas en este artículo. 
La incoación de un proceso judicial y, en concreto, del llamado "juicio plenario", tenía lugar cuando un acto sexual reprobable era denunciado y admitido a trámite por la justicia criminal. Los acusados, entonces, eran declarados formalmente presos y debían nombrar un abogado que garantizara su defensa. Aquellos que no pudieran costearse la defensa tenían derecho a disfrutar de un abogado de pobres, letrados nombrados por el gobierno que ejercían sus funciones en los juzgados de letras del Distrito y en la Suprema Corte de Justicia a cambio de seiscientos pesos anuales, un sueldo insuficiente, en atención a lo declarado por el jurista Manuel de la Peña y Peña, que los obligaba a compaginar su oficio con otras actividades para garantizar su estatus en la capital (De la Peña, 1835: 153). ${ }^{2}$

En relación con los abogados privados, las leyes recomendaban que sus honorarios se acordaran antes de la prestación de sus servicios, aunque, en la práctica, solían cobrar a medida que iban realizando su trabajo, en función, además de su reputación, de la causa que se versaba, del interés que mediaba, del trabajo que se invertía y, por supuesto, del resultado final (De la Peña, 1835: 327-328 y 333334). Ganar un juicio, por tanto, además de repercutir sobre el estatus del letrado, por tanto, podía implicar una mayor remuneración por sus funciones.

Para ser abogado había que ser varón mayor de 17 años y, desde 1830, contar con tres años de formación en Derecho, avalada por la Academia de Derecho Teórico-Práctico a cargo del Colegio de Abogados, antes de ser examinado por la Corte Suprema de Justicia, organismo encargado de calificar al pasante. ${ }^{3}$ Legalmente estaba prohibido por la ley de Partidas que los "sordos", "locos" y las mujeres ocuparan ese cargo (Partida 3.6.3). El veto impuesto a las mujeres fue justificado en el ámbito jurídico, al asumir que el tachado en la época como "sexo débil" era también incapaz de controlar su carácter. "Cuando pierden

\footnotetext{
En la ciudad de México existían cuatro abogados de pobres. En caso de necesidad, los letrados llamados para tal fin, en teoría, no podían rehusarse a defender a aquellas personas que carecieran de recursos y solicitasen sus servicios (De la Peña, 1835: 341342 y 345-346). En relación con los salarios aludidos y la desigualdad que caracterizó a la capital durante la centuria, consideremos que el salario fabril femenino a mediados de siglo podía oscilar entre los 288 y los 360 pesos anuales (Ramos, 1987: 157).

3 Ley Sobre el tiempo necesario de práctica para examinarse de abogado, 28-VIII1830, art. 1, en Dublán y Lozano (1876: 284).
} 
la vergüenza es fuerte cosa de oírlas e de contender con ellas", sostenía al respecto De la Peña, añadiendo que su actuación como letradas supliría la justicia con insultos (De la Peña, 1835: 312).

Con el objeto de conocer las principales tendencias argumentativas adoptadas por quienes representaron a acusados y acusadores en procesos por delitos sexuales perpetrados por mujeres o contra mujeres, hemos analizado seiscientos ochenta y cuatro expedientes judiciales pertenecientes al fondo Tribunal Superior de Justicia del Distrito Federal (TSJDF) del Archivo General de la Nación de México (AGNM), relativos a procesos incoados en la ciudad de México entre 1827 y 1871, además de leyes, artículos, diccionarios y tratados de Derecho. ${ }^{4}$ Nuestro marco temporal responde al interés por conocer parte del funcionamiento de las instituciones judiciales en los primeros momentos de la independencia política del país y antes del legalismo teóricamente implementado con la promulgación del Código Penal de $1871 .{ }^{5} \mathrm{Si}$ bien, como demostró Elisa Speckman, el código no puso fin de forma inmediata a la supervivencia de un pluralismo normativo, pues en la práctica judicial la ley y la norma siguieron sin equipararse (Speckman, 2006), encontramos que las intervenciones de los abogados para después de este periodo fueron más escuetas y presentaron características propias, motivo por el que hemos cerrado nuestro estudio con la promulgación de este cuerpo legal. ${ }^{6}$

Durante los primeros cincuenta años de independencia del país, en la práctica letrada las circunstancias de cada caso primaron sobre las leyes. Para ello, los abogados, al elaborar sus alegatos, centraron su atención en la "calidad" de las personas implicadas en los proce-

\footnotetext{
$4 \quad$ Si bien el fondo documental ha sido revisado en su totalidad para el periodo contemplado en este estudio, no hemos incluido aquí seis expedientes relativos a procesos en los que la determinación de la culpabilidad de los reos estuvo a cargo de un jurado popular, al considerar que, en ellos, los discursos de los abogados adquirieron condiciones distintas a las expuestas en este artículo. Sobre las características y el funcionamiento del jurado popular en México puede consultarse Ovalle, 1981; Padilla, 2000 y Speckman, 2005.

5 El motivo por el que iniciamos nuestro estudio en 1827 y no ya en 1821, año de la declaración de la independencia del país, estriba en las características del fondo documental examinado. No hemos podido encontrar ningún expediente por delitos sexuales anterior al año referido.

6 Afirmación sustentada en el análisis de treinta expedientes por delitos sexuales incoados entre 1872 y 1880.
} 
sos, tratando, con ello, de legitimar o desacreditar sus testimonios, así como de agravar o tratar de relativizar el acto juzgado. ${ }^{7}$ A pesar de que su acción difirió en cada caso, ha sido posible rastrear en este estudio líneas comunes en las argumentaciones esgrimidas, referencias reiteradas que permiten afirmar la existencia de ciertas inclinaciones ideológicas predominantes entre los letrados.

Sus discursos han sido interpretados como medios de interacción social (Antaki y Condor, 2000: 453), posibilitados por categorías cognitivas compartidas (Van Dijk, 2000: 36) que constituyen elementos activos en la creación de significados (Cabrera, 2003: 209-211). En atención a sus condiciones de producción, por tanto, no han sido leídos como instrumentos veraces para conocer el devenir de los hechos procesados, sino como un medio para dilucidar las estrategias defensivas empleadas, lo que nos ha permitido acercarnos a un código de valores compartido por esta elite judicial. Al considerar que su finalidad no era otra que la de ganar los juicios, interpretamos que los estereotipos, prejuicios y descalificaciones recurridas por los abogados buscaban suscitar la complicidad de las autoridades, constituyendo así, por tanto, “discursos públicos" (Scott, 2000: 27-28), reproductores y promotores de un determinado imaginario sociocultural. Contemplamos también que la relevante posición que los juristas ocuparon en la vida cultural y política del país durante la centuria (Berrueco, 2006), dotó a sus manifestaciones discursivas de una influencia notable en los procesos de significación social. Con nuestro trabajo, buscamos coadyuvar a explicar algunas de las características de esta cultura jurídica, ${ }^{8}$ lo que creemos resulta crucial a la hora de escribir la historia del funcionamiento de las instituciones de justicia y su contribución al establecimiento de un determinado sistema sexo-género. ${ }^{9}$

\footnotetext{
Este casuismo, basado en las calidades personales, fue una constante en el Derecho penal del Antiguo Régimen (Tomás y Valiente, 1969: 331-351).

8 Compartimos la definición de "cultura jurídica" de Jorge Baraona, quien la define como "el ethos que explica la manera de entender, aplicar y enseñar el Derecho" (Baraona, 2010: 428).

9 Empleamos aquí el ya clásico concepto desarrollado por la antropóloga Gayle $\mathrm{Ru}$ bin, según la cual el sistema sexo-género estaría formado por el "conjunto de disposiciones por el que una sociedad transforma la sexualidad biológica en productos de la actividad humana y en el cual se satisfacen esas necesidades humanas transformadas" (Rubin, 1986: 97).
} 


\section{Ley, doctrina, costumbre e imaginación}

En teoría, como recogía el tratadista Anastasio de la Pascua, la actuación de los abogados debía limitarse a "la narración verdadera de los hechos, a la aplicación clara de estos a las leyes y a la exposición sencilla de aquellas razones naturales y verosímiles que ofreciesen las circunstancias de las personas y de los acontecimientos" (De la Pascua, 2010: 338). Según juristas contemporáneos, como De la Peña, de la misma forma que no debían encargarse del patrocinio de una causa injusta, los abogados tampoco debían defender una causa contra leyes expresas que estuvieran vigentes, ni aun bajo el pretexto de que hubiera autores que impugnaran sus disposiciones (De la Peña, 1835: 301-302). Los autores debían, según este razonamiento, "callar ante las leyes", pues en Derecho no debía juzgarse por lo que dijeran los comentadores, según argumentaba el abogado Matías Fernández en un proceso por incesto. ${ }^{10}$

En la práctica, sin embargo, los argumentos esgrimidos por estos profesionales de la oratoria, lejos estuvieron de ceñirse a la aplicación de la normativa vigente. Mediante el recurso continuado a las opiniones de los autores y haciendo uso de las armas de la elocuencia, los abogados trataron de deslumbrar o conmover a los jueces, contradiciendo o relegando a las leyes a una posición secundaria, en más de una ocasión. Juristas como De la Pascua se mostraron partidarios de mantener esta tendencia, considerada parte integrante del oficio de la abogacía, defendiendo el mantenimiento de "las artes de la imaginación" en el foro, en detrimento de un "desnudo" y "árido raciocinio" que, supuestamente, los defensores del legalismo trataban de imponer (De la Pascua, 2010: 339).

Hasta la implantación del Código Penal, la caída en desuso de las leyes medievales, "dictadas en tiempos poco menos que bárbaros", según el abogado Agustín Coria, y la ausencia de nuevas medidas que lograran revocarlas, habían causado, como ya comentamos, un vacío normativo suplido por la doctrina recogida por juristas en diversos manuales, diccionarios y tratados de derecho. ${ }^{11}$

$10 \quad$ AGNM, TSJDF, 1834, caja 94, exp. 48, “Toca a la causa instruida contra D. Mugye Rodríguez, doña Zeferina Subeldia e Ignacio García por incesto", s/f.

11 AGNM, TSJDF, 1857, caja 324, “Averiguación contra Cresencio Martínez por fuerza y estupro con María Senovia”, f. 13r. 
"Si las leyes hubieran de aplicarse sin atener a las circunstancias de los pueblos en que fueron dictadas, si pretendiera dárseles toda la extensión de su tenor literal en aquellas regiones a donde han sido llevadas por un conquistador o adoptadas en defecto de instituciones propias, y de consiguiente más acomodadas al carácter, costumbres y temperamento de sus naturales, en vez de los saludables efectos que se tuvieron presentes al dictarlas producirían los contrarios y diametralmente opuestos". ${ }^{12}$

De esta forma, el abogado Mariano Urruchi justificaba la necesidad de matizar la normativa vigente con el Derecho común. Si bien el objetivo de los tribunales no era otro que el de aplicar las leyes que no habían sido expresamente derogadas, según este letrado, multitud de ellas, principalmente las penales, se hallaban "tan olvidadas como si nunca hubiesen existido."13 Siguiendo esta lógica argumental, era pues necesario que una firme discreción precediera siempre a la calificación de los delitos y a la imposición de las penas que a ellos correspondían, para no cometer las injusticias que, ante los principios humanistas, individualistas, secularizadores y liberales contemporáneos, derivarían de un riguroso apego a la legalidad.

$\mathrm{Al}$ respecto, la vigencia de la férrea legislación medieval que regulaba los ilícitos sexuales permitía establecer desde duras condenas de vergüenza pública y galeras, hasta azotes y muerte por ahorcamiento, frente a delitos comúnmente tolerados por las autoridades, como era el caso del lenocinio, definido en la época como el "infame comercio de prostitución de mujeres", antes de la reglamentación de esta actividad en $1865 .{ }^{14}$ Correspondía a los abogados tratar de disuadir a los jueces de aplicar la normativa formal vigente, haciendo llamamientos tanto a las circunstancias específicas del caso como a la costumbre, como advertimos en el proceso de 1838 contra la anciana Ana Flores. Después de años regentando un prostíbulo como madama, Flores fue

\footnotetext{
12 AGNM, TSJDF, 1830, caja 58, exp. 78, "Expediente supletorio del formado contra D. Juan Fenzi por estupro", s/f.

13 AGNM, TSJDF, 1830, caja 58, exp. 78, "Expediente supletorio del formado contra D. Juan Fenzi por estupro", s/f.

14 Sobre el proceso de reglamentación de la prostitución que tuvo lugar en la ciudad de México, en 1865, centrado en el aislamiento y el control de las mujeres, nunca de los hombres, véanse: Bailón, 2008; Núñez, 2002; Ramos, 2006 y Tuñón, 1991.
} 
detenida una noche en la que, después de una pelea desatada en el interior del burdel, un hombre muriera asesinado.

Pese a demostrarse su inocencia en el homicidio, José María Puchet, juez de primera instancia, le imputó el cargo de "lenona", algo imposible de negar al albergar dicho establecimiento en su propia casa. Condenada a cuatro años de servicio en cárcel, Flores apeló la sentencia ante la Suprema Corte de Justicia a través de un abogado de pobres, el licenciado Francisco González, quien, en vista de no poder mostrar su inocencia, trató de relativizar el crimen, recordando la falta de observancia de las leyes y la costumbre judicial de moderar las penas en que hubieran incurrido los contraventores:

"Es verdad que la legislación antigua imponía penas muy severas a las lenonas y que estas leyes no han sido derogadas por obras, pero sí es cierto que estas leyes han caído en desuso, como ha sucedido con todas las que hablan de delitos carnales, es notorio que esta Ley no está en práctica porque ¿a qué autoridad se ha visto se le exija la responsabilidad porque no las ha perseguido como debía? No puede decirse es por ignorancia pues es notorio la multitud de casas de prostitución que hay en esta capital y de cuya existencia se ha tratado más de una vez por los periódicos".15

Mayor relevancia que el delito cometido tenía, desde esta imperante perspectiva, por tanto, quién, cómo, cuándo, dónde y por qué perpetraba el mismo. La diversidad de opiniones de los tratadistas ante una misma situación delictiva complejizó el Derecho, al llenar la legislación de enrevesados comentarios. Según la valoración formulada por el fiscal de la Suprema Corte de Justicia, Juan Bautista Morales, esta situación en la práctica judicial había instaurado la "pésima costumbre" de considerar la opinión de los autores por encima de las leyes, lo que complejizaba aún más la labor de los letrados (Morales, 1857: 67). Con una gráfica representación, Morales describía las trabas que un letrado debía sortear en el ejercicio de sus funciones de la siguiente manera:

"Va un abogado instruido con una que terminantemente decide el negocio en su favor: se presenta en estrados; informa victoriosamente, y cuando cree que va a lograr el triunfo y que su contrario

\footnotetext{
15 AGNM, TSJDF, 1838, caja 132, “Causa de Ana Flores por lenona”, ff. 43r-43v.
} 
no tiene una sola palabra que objetar, ve que se le vuelve polvo y ceniza entre las manos, y tiene el dolor de perder el pleito, porque así lo quieren Vela, Castillo, Molina y los jueces, que han acatado mejor a las opiniones de estos autores, que a la letra de la ley" (Morales, 1857: 67).

En un marco normativo tan voluble, la abogacía, más que una ciencia, era un arte para el que no todos los licenciados en Derecho estaban preparados. Conocer la ley y la doctrina debía combinarse con saber modular la voz, fijar la mirada, pausar la respiración y elegir bien los tropos a la hora de construir el discurso de la defensa. Su objetivo no era otro que ganar el juicio, cautivando a los magistrados con su oratoria, para lo que había que ser rápido a la hora de elegir bien a los testigos, solicitar las pruebas adecuadas y, sobre todo, relativizar o resaltar las circunstancias que envolvían la supuesta comisión delictiva. De esta manera, los letrados desarrollaron diversas estrategias a la hora de representar a acusados y acusadores. Al respecto, como veremos a continuación, tratar de que el juicio fuera declarado nulo, mediante el veto a la acusación o la denuncia de irregularidades procesales, e invalidar pruebas y testigos figuraron entre los recursos más empleados. Ante la constatación irrefutble de la comisión delictiva, por otro lado, la defensa de los acusados trató de ganar la mayor lenidad judicial, haciendo referencia a la calidad de los implicados en los ilícitos, con base en un conjunto de valores y prejuicios compartidos.

\section{La nulidad en la estrategia legal}

La nulidad era la principal estrategia de la que podía valerse un abogado en el foro (De la Pascua, 2010: 340). Esta consistió en la negación de la validez del proceso, bien por la falsedad del delito que se imputaba, bien por alguna irregularidad procesal.

\section{Veto a la acusación}

Uno de los recursos de nulidad más utilizados por parte de los abogados en los delitos tratados fue la deslegitimación de la parte acusadora, principalmente cuando las acusaciones eran formuladas por mujeres. Al respecto, en atención a la regulación del delito de adulterio, este había quedado definido en las Partidas como el "error" que un hombre hacía "a sabiendas acostándose con mujer casada o comprometida 
con otro" (Partida 7.17.1). Al considerar a la mujer como "lecho de su marido" y no al contrario, el adulterio, interpretado como "romance como lecho dotro", causaba deshonra sólo en el esposo afectado, motivo por el que se consideraba un delito exclusivamente femenino y por el que las mujeres habían quedado incapacitadas para acusar ante las autoridades judiciales el adulterio marital, lo que convertía al hombre en el único facultado para tal acción (Partidas 7.17.1 y 7.17.2).

Pese a ello, el complejo enjambre legal que reguló estos ilícitos antes de la codificación penal dio cabida a diversas fisuras que permitieron la formulación de acusaciones femeninas vetadas por la ley y que, en la práctica judicial, el adulterio masculino fuera castigado. Así, por ejemplo, en atención a lo recogido en la Novísima Recopilación, el marido que acusara de adulterio a su mujer, para que su acusación fuese válida, debía dirigirla en contra tanto de la mujer como del supuesto amante (Novísima Recopilación, lib. XII, tít. 28, ley 3). Si bien esta medida se refería únicamente a los maridos, en 1844 el juez Ignacio Jáuregui estimó también correcta su aplicación en el caso de que la demandante fuese una mujer, justificando la puesta en libertad de Nicolasa González, acusada de haber estado amancebada con Melquíades Guerra durante meses, en vista de no tener la esposa, Eugenia González, acusación de adulterio contra el marido. ${ }^{16}$ Paradójicamente, un mes después, el mismo juez, ante la acusación de adulterio que caía sobre José Soriano y Guadalupe Mejía, hecha por la mujer de Soriano, tras tomar declaración a los dos acusados y sin haber mandado hacer ninguna averiguación posterior, los puso de inmediato en libertad "por no tener facultad la mujer para acusar de adulterio".17

Como vemos, en dos casos de la misma naturaleza el juez Jáuregui justificó sus sentencias mediante argumentos opuestos -la incapacidad de las esposas de hacer una acusación de adulterio y la necesidad de que estas dirigiesen su queja contra sus maridos y las respectivas amantes-, evidenciando la existencia de una flexibilidad interpretativa del marco legal y, por ende, de un amplio arbitrio judicial. Al respecto, la mejor forma de evadir estos impedimentos formales consistió en cambiar la tipología del acto delictivo demandado, denunciando a los 
maridos infieles por las consecuencias que sus extravíos podían tener. Si bien un marido podía cometer adulterio y quedar impune, no podía, por ello, abandonar sus obligaciones familiares de proveedor y protector, ni causar escándalo con sus ilícitas amistades, pues, con ello, cometería un delito de amancebamiento o concubinato. ${ }^{18}$

Los abogados, conscientes del valor clave de estos pequeños matices, se esforzaron por tratar de deslegitimar la capacidad acusadora de la parte contraria y de defender el de la propia mediante estrategias discursivas. Así, frente a la acusación de Petra Velasco contra Guadalupe Hernández por haber mantenido una amistad ilícita con su marido, los abogados de ambas partes se enzarzaron en una disputa terminológica pues, como defendía la parte acusadora, la incontinencia que se juzgaba era pública y, por ende, cualquiera estaba capacitado para formalizar su acusación. Sin embargo, según la defensa contraria, al tratarse de una acusación de adulterio y no de concubinato, sólo la parte agraviada podía acusar y, en este caso, el juez había declarado por no parte a Petra Velasco, al no poder la mujer acusar de adulterio, por lo que el proceso debía sobreseerse. ${ }^{19}$

En atención a las Partidas, las mujeres casadas tampoco podían demandar a sus maridos por otros delitos, en caso que pudiera "venir de ello pena corporal”, por lo que una mujer, según el abogado Ignacio Carreño y Palacios, no podía acusar a su marido de un delito de violación. ${ }^{20}$ Ante un delito de estupro, aunque este fuese inmaturo, por otro

\footnotetext{
18 El trato ilícito y habitual entre un hombre y una mujer, considerado "amancebamiento", recibía la designación de "concubinato" cuando implicaba escándalo (De la Pascua, 2010: 68). A pesar de su caída en desuso, las leyes contemplaban severas penas de destierro y azotes para los hombres casados que cometieran estos delitos (Novísima Recopilación, lib. XII, tít. 26, leyes 1-4). Desde 1859, como quedó recogido explícitamente en la Ley de Matrimonio Civil, la obligación marital de proteger a la esposa a cambio de obediencia, recogida en la legislación colonial, quedó refrendada, reconociendo explícitamente que el marido tenía la obligación de proteger, alimentar y guiar a la mujer, quien, a su vez, debía obedecer, agradar, asistir, consolar y dar consejo a su cónyuge.

19 AGNM, TSJDF, 1828, caja 38, "Toca al expediente promovido por Doña Petra Velasco contra Doña Guadalupe Hernández por ilícita amistad de esta con el marido de la primera", s/f. Según las leyes, el adulterio se consideraba un delito privado, perseguible sólo a instancia de parte (Novísima Recopilación, lib. XII, tít. 28, ley 3).

20 Razonamiento expuesto por el abogado Ignacio Carreño y Palacios con base a la P. 3.2.5 citada en su alegato. AGNM, TSDF, 1848, caja 253, "Toca a la causa instruida contra Clemente Cordero por conato de estupro y fuerza", f. 4r. La referida ley de Partidas recoge que: "Y otras demandas no se deben mover nacidas de calumnia o mala fama, o porque tengan que recibir pena corporal mientras dure el matrimonio, excepto en razón
} 
lado, si bien la ley permitía que cualquiera formalizase la acusación contra el responsable, la doctrina se inclinaba cada vez más a limitar este derecho a la parte agraviada, argumento expuesto por el abogado José María Angulo, quien trató sin éxito de deslegitimar la acusación que caía sobre su cliente, Clemente Cordero, condenado a un año de obras públicas por haber tratado de violar a una niña que tenía a su cuidado, ya que, en este caso, había sido la propia esposa de Clemente quien lo había denunciado. ${ }^{21}$

Otro instrumento recurrido por los abogados para deslegitimar las acusaciones femeninas, consistió en convencer al juez de que las demandantes se movían impulsadas por la "ceguera de los celos". Eran de sobra conocidos en el foro "los caprichos" que por celos formaban las mujeres "con demasiada imprudencia", según afirmaba el abogado Antonio Salamanca al referirse a la esposa de su defendido, quien lo había acusado de violar a su entenada. ${ }^{22}$ De la misma manera, ante la demanda de la amante de José Trinidad de haber mantenido relaciones con la niña que esta tenía a su cargo, el abogado defensor Juan Molina acusó a la actora de querer vengarse de Trinidad, "instigada por la furiosa pasión de los celos por el desaire y desprecio que le hizo", tratando, así, de invalidar su acusación. ${ }^{23}$

\section{Irregularidades procesales}

La comisión de alguna informalidad judicial proscrita por la ley durante el proceso también podía ser utilizada por la defensa para tratar de anularlo y evitar, así, la condena del reo. Como sostenía el letrado Buenaventura Lozano, los abogados también debían patrocinar a las

de adulterio". Para evitar confusiones, a pesar de las distintas significaciones de la época, empleamos aquí el término "violación" en la acepción contemporánea, recogida en la obra de Escriche, de "violencia que se hace a una mujer para abusar de ella contra su voluntad" (Escriche, 1852: 1538).

${ }^{21}$ Cometía estupro inmaturo aquel que estupraba, es decir, tenía acceso carnal con una doncella menor de doce años por medio de la fuerza física o moral (De la Pascua, 2010: 109). El estupro sobre doncella que no hubiese alcanzado la pubertad debía castigarse siempre con pena corporal al arbitrio del juez, según las circunstancias (Escriche, 1852: 653).

$22 \quad$ AGNM, TSJDF, 1832, caja 76. “José Asensio Mejía por estupro”, f. 45v.

23 AGNM, TSJDF, caja 119, 1837, exp. 23, “Toca a la causa de José Trinidad García y Ramona Pérez por incesto", f. 25r. En el lenguaje judicial, el “actor” o “acusador” era aquel que provocaba o movía el pleito, "demandando alguna cosa o derecho” (De la Peña, 1835: 7-8). 
partes contra las ilegales determinaciones de los jueces que, por malicia o ignorancia, contravinieran las leyes expresas. ${ }^{24}$

Desde 1812, por mandato constitucional, aquellos empleados públicos, incluyendo los jueces, que no cumplieran con la observancia de las leyes en el ejercicio de sus funciones debían de ser sancionados. ${ }^{25}$ Durante el periodo considerado en este estudio, sin embargo, la aplicación de esta normativa se vio obstaculizada por la situación de pluralismo normativo y la inexistencia de un orden de prelación fijado por la ley, lo que impulsó el ejercicio de un amplio arbitrio judicial que dificultó, en la práctica, la exigencia de responsabilidades judiciales por desapego a la ley. ${ }^{26} \mathrm{~A}$ esta complicación se sumó la jerarquía existente entre los integrantes del foro y el elevado puesto ocupado por los jueces letrados, lo que hacía que, según algunos abogados, para la década de los años treinta los recursos de responsabilidad hubiesen quedado ilusorios. ${ }^{27}$

Pese a ello, entre los expedientes por delitos sexuales analizados pudimos encontrar un caso en el que el abogado de una de las partes enfrentadas solicitó procesar al juez encargado, por haber cometido una irregularidad en el proceso. En concreto, se trató de un ocurso presentado ante la Suprema Corte de Justicia por el licenciado Buenaventura Lozano, solicitando la suspensión del juez de primera instancia José Manuel Zozaya Bermúdez, por su actuación en la causa por adulterio seguida contra la mujer de su defendido, el francés Don Pedro Oubrat. ${ }^{28}$ Pese a no contar con la resolución del juicio de responsabilidad, el cruce de acusaciones y ataques descalificativos entre juez y abogado nos ha permitido acercarnos al complejo universo de la elite

${ }_{24}$ AGNM, TSJDF, 1837, caja 124, exp. 4, "Ocurso de Don Pedro Oubrat contra el Lic. Don M. Zozaya", ff. 15r-15v.

25 Esto se sancionó en la Constitución Española de 1812, artículo 131.

26 Como afirma Elisa Speckman: "No era posible, pues los jueces debían buscar entre un universo legal amplio la norma más adecuada a su caso. Transitaban por cinco siglos de leyes y por dos diferentes órdenes jurídicos. Era, por tanto, imposible responsabilizar a un juez por elegir una norma no exactamente aplicable al caso, pues habría que empezar por discutir cuál de ellas era la que más se ajustaba y en esta elección los criterios podían variar" (Speckman, 2015: 51).

${ }_{27}^{27}$ "Me fundé para ello en la constante experiencia que por desgracia me lo ha acreditado", aseguraba el letrado. AGNM, TSJDF, 1837, caja 124, exp. 4, “Ocurso de Don Pedro Oubrat contra el Lic. Don M. Zozaya", f. 14v.

${ }_{28}$ AGNM, TSJDF, 1837, caja 124, exp. 4, “Ocurso de Don Pedro Oubrat..., ff. 1r-40v. 
letrada desde la particular perspectiva del enfrentamiento. De esta manera, hemos sido conocedores de algunos de los valores y prejuicios compartidos, en este caso, por uno de los magistrados encargados de sentenciar un importante número de los juicios por delitos sexuales considerados en nuestro estudio. ${ }^{29}$

José Manuel Zozaya, encargado de llevar a cabo las primeras averiguaciones sobre el supuesto delito de adulterio cometido por Doña Eugenia Segant, ordenó que el escribano y el ministro ejecutor de su tribunal acudieran junto con el actor a la casa de su esposa con objeto de sorprender a esta y su amante viviendo juntos y maridablemente y determinar, así, los motivos para materializar su aprehensión. ${ }^{30}$ Una vez llegados al domicilio y sin entrar en los cuartos donde vivían los acusados, el ministro ejecutor consideró que no había indicios delictivos apreciables. Cuando se encontraba dispuesto a proceder al llamamiento de testigos de la parte acusadora, el magistrado recibió un oficio del juez Ybarra suscitando competencias de jurisdicción, por lo que dejó de encargarse del proceso. Ybarra, tras continuar la averiguación, resolvió el caso, considerando que no existían motivos para detener a la esposa de Oubrat. ${ }^{31}$

Como puso de manifiesto el licenciado Buenaventura en su ocurso, ni el escribano ni el ministro ejecutor estaban facultados para calificar indicios delictivos, siendo esta una competencia exclusiva del juez ${ }^{32}$. En relación con el modo de obrar del juez, el abogado recomendaba en su suspicaz discurso: "impóngase Don Manuel Zozaya de sus obligaciones, estudie nuestra constitución [sic] y aprenderá a quién está exclusivamente reservada la facultad de dar jurisdicción, o lo que es lo mismo, de hacer jueces".

\footnotetext{
$29 \quad$ El juez José Manuel Zozaya fue el encargado de procesar en primera instancia once de los juicios analizados entre 1827 y 1845. Su continuidad como juez de letras de la capital, en los años posteriores al juicio de responsabilidad citado, permite deducir que no fue condenado por la Suprema Corte de Justicia a abandonar su cargo o que la suspensión fue temporal.

30 El cargo de ejecutor consistía en "llevar a efecto alguna provisión o mandamiento de la autoridad judicial". Las personas que, por orden judicial, llevaban a cabo ejecuciones o cobranzas recibían el nombre de "ejecutores" (Escriche, 1852: 599).

31 AGNM, TSJDF, 1837, caja 124, exp. 4, “Ocurso de Don Pedro Oubrat...," ff. 1r-40v.

32 AGNM, TSJDF, 1837, caja 124, exp. 4, “Ocurso de Don Pedro Oubrat...”, f. 15r.
} 
A pesar de tratarse de un magistrado reconocido y "temido por el público", el abogado Buenaventura no tuvo reparos en su ocurso de tachar al juez de ignorante, malicioso y monstruoso, desatando la ira de Zozaya, quien lamentó la "facilidad pedantera con que suelen producirse algunos jóvenes sólo porque han recibido el título de abogado" y mostró su peculiar patriotismo, afirmando que se consideraba altamente ofendido por un "miserable extranjero", en referencia al origen francés de Oubrat. ${ }^{33}$ No es de extrañar que el enfrentamiento relatado aparezca como excepcional en el fondo documental revisado ya que, en general, los prejuicios y simpatías de los magistrados, así como el complejo y plural derecho vigente por parte de los propios jueces ante determinados delitos, hacía de la persuasión una herramienta más útil que el enfrentamiento a la hora de planear la defensa en un juicio criminal como el considerado.

\section{Invalidez de pruebas y testigos}

En caso de no poder deslegitimar a la parte acusadora, y viendo los inconvenientes que atentar contra el ejercicio judicial podía tener, los abogados iniciaban una batalla para desacreditar lo afirmado por los testigos de la parte contraria, con nuevos testigos o tachando a los presentados, así como para anular las pruebas materiales, sobre todo cuando se trataba de los resultados obtenidos por el reconocimiento genital de parteras en los casos de estupro y violación.

En lo referente a la tacha de testigos, la relación de amistad y parentesco que pudiese haber entre estos y las partes enfrentadas fueron elementos muy recurridos por los abogados. Más interesante, sin embargo, se mostraron otros motivos por los que los letrados consideraron que un determinado testigo debía de ser invalidado, al recoger en sus argumentos un conjunto de valores y prejuicios racistas, clasistas y de género que, consideramos, fueron compartidos por la elite del foro. Ser indígena, ignorante, ebrio consuetudinario, jugador, vago o tener una conducta sexual desarreglada en el caso de las mujeres, fueron elementos con los que los letrados creyeron poder obtener el favor de los

33 Según Buenaventura, ningún periódico había querido publicar el auto por miedo a las represalias que el juez pudiera promover. AGNM, TSJDF, 1837, caja 124, exp. 4, "Ocurso de Don Pedro Oubrat...," f. 5v y 15r. 
jueces para desprestigiar los testimonios ofrecidos por la parte contraria. De esta forma, al tratar de deslegitimar a la testigo María Dolores, quién había declarado en contra de Doña Guadalupe Hoyos, acusada de adulterio, el licenciado Ignacio Castro llamó a varios vecinos con el objeto de tachar su testimonio, preguntándoles si esta no era "una india estúpida tonta y mazorral fácil de seducir por su mucha y crasa ignorancia". ${ }^{34}$ En la misma dirección, los abogados Matías Fernández y Miguel Rodríguez tacharon de increíbles las declaraciones del temascalero Ignacio García y su mujer Guadalupe Benavides, en consideración de su "rusticidad", además de ser "indignos de todo crédito" por su condición de domésticos. ${ }^{35}$

En relación con la prueba material de los delitos de estupro y violación, los métodos más recurridos para su investigación fueron los exámenes corporales llevados a cabo por médicos y parteras, y realizados -principalmente- sobre los genitales de las víctimas con el objeto de encontrar señales de desfloración, violencia o enfermedades venéreas contagiadas (Palafox, 2017a). A lo largo de la centuria, la posición de los tratadistas frente a este método probatorio no fue unánime. Así, mientras que para algunos, como el jurista Joaquín Escriche, se trataba de una constatación material legítima, siempre que fuera realizada por médicos (Escriche, 1852: 655), otros, como Senén Vilanova, en atención al pudor debido, recomendaban siempre la presencia también de matronas (Vilanova, 1827: 204). Su efectividad también estuvo en disputa y autores como De la Pascua o Juan N. Rodríguez de San Miguel, se mostraron desconfiados ante la posibilidad de constatar la comisión delictiva mediante el deconocimiento de las supuestas marcas físicas que el coito dejaba en las mujeres (De la Pascua, 2010: 249 y Rodríguez, 1852: 441).

Algunas de las divergencias constatadas en los principales manuales forenses sobre la adecuación de estas prácticas pudieron apreciarse también en los discursos que los letrados pronunciaron al respecto.

\footnotetext{
34 AGNM, TSJDF, 1832, caja 77, "A la causa instruida contra Guadalupe Hoyos acusada de adulterio", s/f.

35 Un temascalero es aquel que se ocupa de cuidar un temascal, estructura baja de adobe donde se toman baños de vapor. AGNM, TSJDF, caja 94, 1834, exp. 48, "Toca a la causa instruida contra Don Mugye Rodríguez, Doña Zeferina Subeldia e Ignacio García por incesto", s/f.
} 
Así, a pesar de que cada uno se posicionó sobre el tema movido por sus particulares intereses, la tendencia predominante respecto de esta actividad fue la de tratar de tacharla de impúdica y cuestionar los resultados obtenidos, sobre todo cuando estos provenían del análisis realizado por parteras. ${ }^{36}$ De esta manera, algunos abogados se refirieron a esta práctica como "una diligencia que ofende a cualquier ramera, ${ }^{37}$ una "práctica imperfecta, maléfica y abusiva" y una "violación completa de la virginidad de la inocencia y el pudor" ${ }^{\prime 3}$ Su efectividad, además, fue cuestionada sobre todo en lo referente a su capacidad de verificar la responsabilidad de un acusado en un acto de desfloración o violación. Al respecto, el abogado Matías Fernández sostenía: "la naturaleza muda la forma de la mujer que deja de ser doncella, pero no consiente que el desflorante (sic) imprima su nombre en el lugar donde verifica su acto"39

Los ataques fueron mucho más notables cuando los exámenes eran realizados por matronas y no por médicos de "genial probidad", pues la autoridad académica de los facultativos se tradujo, en la práctica, en una predominante alianza con la elite judicial. ${ }^{40}$ Haciendo referencia al estatus o capital simbólico que la formación en Derecho daba a los magistrados, los abogados trataron así de resaltar la informalidad que acompañaba a la partería (Bourdieu, 2000: 59). Frente a "hombres científicos" que habían "envejecido en el estudio y práctica de la anatomía", se preguntaba el abogado Agustín Coria, ¿cómo podía merecer atención “ante los ojos de un juez ilustrado una comadrona de un pueblo?".41

\footnotetext{
36 Sólo en tres ocasiones pudimos comprobar el respaldo explícito, siempre interesado, de letrados a la labor realizada por las matronas. AGNM, TSJDF, 1848, caja 253, "Toca a la causa instruida contra Clemente Cordero por conato de estupro y fuerza", ff. 1r-7v; AGNM, TSJDF, 1838, caja 131, "La causa contra José María Jiménez por estupro inmaturo", ff. 44r-51v, y AGNM, TSJDF, 1832, caja 76. “José Asensio Mejía por estupro”, ff. 38r-49v. 37 Expresión del letrado Matías Fernández en AGNM, TSJDF, 1834, caja 94, exp. 48, “Toca a la causa instruida contra D. Mugye Rodríguez, Doña Zeferina Subeldía e Ignacio García por incesto", s/f.

${ }_{38}$ AGNM, TSJDF, 1846, caja 209, exp. 32, "Diligencias de sumaria instruidas contra José María Leiva por robo y conato de estupro", f. 14v.

39 AGNM, TSJDF, 1834, caja 94, exp. 48, "Toca a la causa instruida contra D. Mugye Rodríguez, Doña Zeferina Subeldia e Ignacio García por incesto", s/f.

40 AGNM, TSJDF, 1841, caja 158, "Carrillo Agustina contra su esposo Francisco Olmos por rapto y estupro de María Guadalupe Vázquez", 52v. Sobre la relegación institucional de la partería a una posición secundaria frente a la ciencia médica durante el siglo XIX, véanse Carrillo, 1999, y Radkau, 1994.

${ }^{41} \quad$ Las citas refieren expresiones del letrado Coria en la defensa de Cresencio Martínez, acusado de fuerza y estupro. AGNM, TSJDF, 1857, caja 324, "Averiguación contra Cresencio Martínez por fuerza y estupro con María Senovia”, f. 12r.
} 


\section{El poder de la ignorancia}

Cuando las pruebas parecían irrefutables y la comisión del delito juzgado había quedado plenamente demostrada, era necesario ganar la indulgencia de los jueces restando importancia al ilícito o demostrando que el acto reprobado se había cometido inintencionadamente. "Hay hechos que, aun cuando ofendan a un tercero, no llegan a ser delitos, ya por falta de dolo y culpa, de conocimiento o de libre voluntad", afirmaba al respecto el tratadista De la Pascua (2010: 341).

Dentro de este enfoque casuista, que fijaba la atención en las condiciones y circunstancias bajo las que se producía el delito más que en el delito en sí, los letrados aprovecharon el proceso de transición secularizadora que atravesaba el Derecho tratando en ocasiones de traducir el crimen sexual en una falta moral y pecaminosa, que no merecía ser castigada por la justicia civil al pertenecer al fuero interno de la conciencia. De esta forma, por citar un ejemplo, el acto de "perder, como se dice, a una doncella", haciendo uso de engaños, según el defensor Francisco González, no era un delito, con tal de que no interviniera violencia, sino "un pecado muy grave sujeto al fuero sacramental de la penitencia, más no al fuero externo" y, por tanto, no era digno de recibir un castigo público. ${ }^{42}$ En caso contrario, sería necesario "ensanchar las cárceles", añadía este abogado, dando testimonio de la frecuencia con la que se cometían este tipo de incontinencias penadas por la ley.

Entre los discursos de defensa elaborados por los letrados imperó la premisa de que la ley no debía de ser igual para todos. Paradójicamente, en un momento en el que se tendía hacia el monismo normativo y la igualdad jurídica, la calidad de las personas fue reivindicada como categoría determinante a la hora de medir la gravedad del ilícito. Al respecto, consideremos que, durante los primeros cincuenta años de vida independiente del país, la codificación constitucional mexicana, tanto en su forma conservadora como en la liberal, dio lugar a la formación de un concepto de "ciudadano", comprendido como individuo político autorizado para el ejercicio de la soberanía (Velázquez, 2008: 44), que estuvo caracterizado por la parcialidad y la exclusión de sectores poblacionales en función de su edad y su condición socioeconómica,

42 AGNM, TSJDF, 1838, caja 131, “La causa contra José María Jiménez por estupro inmaturo", f. $46 \mathrm{v}$. 
incluyendo su formación (Núñez, 2010) ${ }^{43}$ Por su parte, la ausencia de reconocimiento de la ciudadanía femenina respondió a una omisión, interpretada con base en la conceptualización de la esfera pública como exclusivamente masculina, normalizando así la masculinización del espacio destinado al ejercicio de la palabra y la acción en la potencialidad política (Arendt, 2009: 12), con la consiguiente relegación de las mujeres a la esfera privada del ámbito doméstico.

Dentro de este panorama político, la minoridad dada a diversos sectores de la población planteó una serie de controversias jurídicas. ¿Eran responsables las mujeres y los menores de los ilícitos sexuales que cometían? ¿Cuáles eran las manifestaciones físicas que alejaban la edad cronológica y la biológica de una persona? ¿Pertenecer a un estrato socioeconómico bajo podía eximir de culpa a aquel que perpetrara un delito sexual con o sin violencia? ¿Lo eximía el hecho de ser indígena? Estas y otras cuestiones quedaron alejadas de lo estipulado por las leyes, conformando, una vez más, el indefinible universo circunstancial que determinaba la valoración de un acto delictivo.

Así, en relación con la variable de género, cuando se trataba de defender a un hombre por haber cometido un acto de incontinencia, la ebriedad y el natural e irrefrenable deseo sexual que lo caracterizaban fueron los argumentos más desarrollados por los letrados para justificar la comisión delictiva ${ }^{44}$. En un intento de forzar a una niña, por ejemplo, según el abogado Francisco Mariscal, el estado de embriaguez del responsable serviría como atenuante, transformando un "conato de estupro" en un "desorden de borrachera" ya que, para el letrado, en un borracho no había deliberación. ${ }^{45}$

\footnotetext{
43 Tan sólo con la promulgación de la Constitución federal de 1857, fueron retirados los requisitos patrimoniales y de alfabetización para el ejercicio de la ciudadanía, vigentes hasta el momento, manteniéndose un criterio de honestidad masculina ligado al trabajo y al cumplimiento de la ley. Las mujeres, sin embargo, siguieron excluidas del disfrute de los derechos políticos con base no ya en su formación o comportamiento, sino en su supuesta naturaleza (Ramos, 2004: 3 y Ortiz, 2007: 324).

${ }_{44}$ Pueden consultarse al respecto: AGNM, TSJDF, 1850, caja 277, exp. 125, “Toca a la causa instruida contra Ramón Oñate por estupro incestuoso", ff. 1r-12v, y AGNM, TSJDF, 1855, caja 307, "Contra Bonifacio Ramírez por conato de forzamiento", ff. 1r-19v.

${ }_{45}$ AGNM, TSJDF, 1855, caja 307, “Contra Bonifacio Ramírez por conato de forzamiento", ff. $13 \mathrm{v}-14 \mathrm{r}$.
} 
Ante casos de violencia sexual, además, resultaba provechoso desprestigiar a la víctima para demostrar que el acto sexual había respondido a una provocación femenina, al tratarse de mujeres "viciadas", carentes de probidad e indignas de crédito, al no haber acatado, antes de la comisión delictiva, el ideal de pudor y castidad integrantes del modelo de feminidad imperante. ${ }^{46}$ Así, en la defensa de José Toribio Medina, acusado de estupro por fuerza física de María Jesús Olvera, el abogado Francisco González trató de demostrar que, en realidad, la víctima se había decidido voluntariamente "a marcharse con aquel presunto seductor, a entregarle su cuerpo, a disfrutar con él de todos los placeres y satisfacciones mutuas de dos amantes jóvenes que precipitaron a vivir de consumo en plena libertad y dedicados exclusivamente el uno para el otro"47 "Suponer fuerza física irresistible o imperio de seducción sobre una mujer tan fácil a las espontáneas voluntariedades y actos de deliberación", proseguía el letrado, era "suponer un error imperdonable contra la inocencia oprimida y contra la razón y buen sentido" ${ }^{\prime 8}$

En la defensa de hombres juzgados por cómplices de adulterio, al haber contraído relaciones con mujeres casadas, tras demostrarse su participación en los ilícitos por los que se les procesaba, los letrados centraron su actuación en tratar de demostrar que sus clientes ignoraban la condición de casada de sus respectivas amantes. En caso de no poder acreditar este desconocimiento, una de las estrategias más frecuentes fue la referencia a la supuestamente natural sexualidad masculina, activa e irrefrenable, lo que los hacía incapaces de resistirse ante las supuestas solicitudes de esposas desamparadas por el abandono de sus maridos.

Esta desolación femenina, causada por el maltrato o la desidia de su cónyuge, en el proceso contra Ignacio Vázquez y Mariana Serrano, juzgados por adulterio en 1855, incluyó la ausencia del débito conyugal, lo que fue hábilmente utilizado tanto por el implicado como por su abo-

46 Expresión utilizada por el letrado Don Vicente Rojas de Abreu en su defensa de Miguel Mendoza, acusado de estupro. AGNM, TSJDF, 1850, caja 277, “Toca a la causa instruida por el juez primero de lo criminal Lic. Contreras contra Miguel Mendoza, José de Jesúsu Mayorga y Juan Cervantes o Covarrubias por robo y estupro", s/f.

47 AGNM, TSJDF, 1841, caja 163, “Toca a la causa contra Toribio Medina y Ángel Vázquez por rapto y estupro", s/f.

${ }_{48}$ AGNM, TSJDF, 1841, caja 163, “Toca a la causa contra Toribio Medina..., s/f. 
gado defensor, Mariano Torres. Según lo afirmado por ambos, Mariana había solicitado que Felipe "dispusiera de su persona", confesándole la mala vida que su marido le daba ya que, además de maltratarla de palabra y obra, sufría una enfermedad que le había dejado impotente. ${ }^{49}$ Para el abogado, un hombre de los "principios de Vázquez" necesitaba de una "virtud heroica" para resistir las afectuosas insinuaciones de una mujer a la que la impotencia de su marido había privado de "los goces del matrimonio".50 $\mathrm{El}$ letrado trató de excusar la actuación de su defendido mediante continuadas referencias al irrefrenable y natural deseo sexual masculino, tratando de resaltar la extraordinaria e irresistible actitud de una mujer al solicitar relaciones sexuales. "La debilidad parece ser una de las dotes de la humanidad", afirmaba Torres, "y cuando a esa debilidad la vemos combatida por pasiones vehementes y que en la mujer tienen tan poderoso influjo la conducen como de la mano a la carreta de los desahucios y extravíos".51

Estas estrategias partían de una misma premisa comúnmente aceptada en el foro: de la misma forma que los hombres estaban dotados por naturaleza de un fuerte impulso carnal, la mayoría de las mujeres nacían limpias de cualquier deseo o impureza sexual. Por este motivo, si retomamos las expresiones empleadas en estos discursos, al contraer relaciones, los hombres "hacían uso" o "disfrutaban" del cuerpo de las mujeres, quienes, con mayor o menor voluntad, se "prestaban" a ello. ${ }^{52}$ Según argumentaba el letrado Coria, de la misma manera que una mujer soltera no ameritaba ninguna probidad para el común entender del foro, era difícil creer que una doncella recatada, cuyo corazón aún no estuviera "pervertido con el impuro comercio con el sexo masculino", pudiera "prestarse voluntariamente a satisfacer los deseos carnales" del primer hombre que se le presentara. ${ }^{53}$

\footnotetext{
${ }_{49}$ Expresión utilizada por el procesado en su declaración ante el juez. AGNM, TSJDF, 1855, caja 308, "Contra Ignacio Vázquez acusado del rapto de la mujer casada Mariana Serrano", s/f.

50 AGNM, TSJDF, 1855, caja 308, “Contra Ignacio Vázquez..., s/f.

AGNM, TSJDF, 1855, caja 308, “Contra Ignacio Vázquez...", s/f.

52 El entrecomillado responde al uso de expresiones frecuentes en los discursos de los letrados para hacer referencia a los diferentes papeles que hombres y mujeres tenían en un acto sexual.

53 AGNM, TSJDF, 1857, caja 324, “Averiguación contra Cresencio Martínez por fuerza y estupro con María Senovia", f. 12r. Por "soltera" en la época se entendía aquella mujer que hubiese sido desflorada sin contraer matrimonio, en contraposición de la virtuosa "doncella".
} 
De acuerdo con un ideal de mujer débil, dependiente de la protección varonil y de un modelo de honradez femenina basado en la contención sexual -ambos promovidos e impulsados durante el proceso de modernización estatal que tuvo lugar a lo largo de la centuria-, una mujer tachada de "deshonesta", además de no ameritar probidad, en caso de que sus "malas mañas" se hicieran públicas, hallaría serias dificultades para encontrar marido, según una opinión extendida en el foro. ${ }^{54}$ Así, para tratar de disuadir al juez de que condenara a Hilaria Ramírez por haber contraído relaciones ilícitas con su cuñado, el abogado Montes de Oca hacía referencia a las consecuencias que conllevaría su condena pues: "cuando sepan que es castigada severamente como pide el ministerio entonces se persuadirán de lo que pasó y lejos de que se le presente marido que todavía pueda encontrar por su regular figura, no tendrá más que seductores que la acaben de corromper".55

Mientras que, de acuerdo con los parámetros de género, ligados al modelo de ciudadanía derivado del sistema productivo que se estaba implantando en el país, para ser considerado un hombre honrado había que esforzarse en el trabajo y mantener a la familia, una mujer que quisiera acreditar su probidad debía de mostrarse casta, inocente, ignorante y débil. ${ }^{56}$ Ante esta situación, frente a acusaciones de adulterio o amancebamiento, ante la imposibilidad de negar el delito, los letrados trataron de demostrar que las mujeres implicadas actuaron

\footnotetext{
54 Mariano Rivera en la defensa de Ignacio González, acusado de rapto. AGNM, TSJDF, 1831, Caja 61, exp. 14, “Ignacio González por rapto de María Ponce”, f. 35v. Para un mayor estudio sobre los estereotipos de género que fueron promovidos desde las instancias políticas y socioculturales a lo largo del siglo XIX, véanse Carner, 1987: 95-109; Gálvez, 2012: 125-150; Ramos, 2004: 93-112 y Ramos, 2006: 799-814. Sobre algunas de las consecuencias que este ideal, materializado en la Ley de Matrimonio Civil de 1859, tuvo en la regulación de los delitos sexuales, véase Palafox, 2013.

${ }_{55}$ AGNM, TSJDF, 1831, caja 65, exp. 33, “Luis Islas e Hilaria Ramírez por incontinencia incestuosa", f. $4 \mathrm{v}$.

${ }^{56}$ El paulatino establecimiento de un modelo político y económico liberal a lo largo del siglo XIX, implicó, entre otros aspectos, la implantación de un sistema librecambista, la abolición formal de un sistema servil y esclavista, y el establecimiento de una igualdad jurídica en el México postindependiente. La costrucción teórica de la ciudadanía, sostenida legalmente en los diversos textos constitucionales que se sucedieron desde 1824, por otro lado, supuso la elaboración de un modelo de ciudadano varón y trabajador (cuando no propietario y alfabetizado), lo que, en la práctica, excluyó a la mayor parte de la población del país de su ejercicio (Ortiz, 2007, y Velázquez, 2008). Este ideal fue reproducido en los principales tratados y diccionarios de Derecho de la época. Véase, al respecto, Escriche, 1852: 100, 1268 y 1305; Vilanova, 1827: 201, y De la Pascua, 2010: 67.
} 
bien coaccionadas por el miedo que sus cómplices les infundían, ${ }^{57} \mathrm{o}$ bien movidas a ciegas por su natural desconocimiento. El género podía ser de por sí un eximente delictivo, ya que al no ser conceptualizadas como sujetos activos, los juristas consideraban que las mujeres no tenían por qué ser conocedoras del Derecho. ${ }^{58}$

"El delito consiste en la transgresión de una ley a sabiendas, de suerte que un loco por ejemplo, aunque perpetre un homicidio no puede decirse que es reo de tal delito, porque ignora lo que hace".59 Con estas palabras el abogado Luis Gonzaga Mena trataba de justificar ante el juez que Josefa Negrete no eran cometedora del delito de incesto del que se le acusaba pues, a pesar de haber mantenido relaciones con Bartolo Velázquez, amante también de la madre de Josefa, esta desconocía el carácter ilícito de dicha unión. "Examine imparcialmente si una mujer de la clase de mi defensa y de su edad que son 15 años podrá tener idea de lo que es incesto y de que existe una ley que prohíbe la unión entre parientes", añadía el letrado, comparando a su defendida con "una barquilla que lucha en las ondas con los vientos bravos" y que, por su ignorancia, había caído en las redes de la seducción de "un hombre corrido".60

Junto con el género, la edad de los acusados fue otro de los recursos más utilizados por los letrados al reclamar una mayor indulgencia judicial. Así quedó de manifiesto en el juicio contra Antonio Bulches y María Olivera, jóvenes primos de dieciséis años, quienes, tras ser acusados por su relación incestuosa, pasaron seis meses en la cárcel durante el tiempo en el que se desarrolló el proceso. Puestos en libertad en primera instancia, al considerar que su pena se encontraba ya compur-

57 Como en la defensa de Doña María Jesús Sarmiento por el abogado Vicente Rojas Abreu AGNM, TSJDF, 1848, caja 257, “Toca a la causa instruida contra Don José Anastasio Escamilla y Doña Jesús Sarmiento por adulterio incestuoso", s/f.

${ }_{58}$ En este caso, la afirmación responde al alegato presentado por el licenciado Francisco González en AGNM, TSJDF, 1838, caja 132, “Causa de Ana Flores por lenona”, ff. 43r$44 \mathrm{v}$. La premisa de que las mujeres debían sufrir penas menores por los mismos delitos, a excepción de los crímenes considerados graves, como los homicidios o el adulterio, estuvo presente en los principales diccionarios y manuales de Derecho, por lo que lo sostenido por este letrado no debe interpretarse como excepcional. Véase, al respecto, De la Pascua, 2010: 15-16, y Escriche, 1852: 66.

59 AGNM, TSJDF, 1842, caja 177, "Contra Bartolo Velázquez y Josefa Negrete por incesto y deserción de tropas el primero", f. 27r.

60 AGNM, TSJDF, 1842, caja 177, “Contra Bartolo Velázquez...., f. 27 r. 
gada por el tiempo pasado en prisión ${ }^{61}$ durante la revisión del juicio, el fiscal, Juan Bautista Morales, apeló la sentencia, pidiendo para ellos tres años de reclusión. A los reos, "confesos en su torpe e incestuosa comunicación" se les debía aplicar un digno castigo con el objetivo de erradicar los "muy frecuentes y escandalosos amancebamientos cualificados con la circunstancia del incesto" que se sucedían en la capital mexicana. ${ }^{62}$ Ante esta situación, si bien las posibilidades que tenía el abogado Pedro Montes de Oca de contrarrestar lo solicitado por un letrado de la talla de Morales eran escasas ${ }^{63}$ el abogado recordó a la Suprema Corte de Justicia que, a pesar de estar demostrada la comisión del ilícito, la edad de los reos disminuía casi toda su malicia, por considerar que la voluntad de una persona de dieciséis años era imperfecta, por lo que su transgresión de la ley apenas merecía castigo. Además de ser "casi pueriles", había que considerar también el descuido en la educación, ya que "la falta de principios religiosos" que habían sufrido influía inevitablemente en su conducta. ${ }^{64}$ "Si el hombre en su infancia no ha recibido aquellas lecciones de moral que son tan necesarias para reprimir sus apetitos, en llegando a la pubertad no se contendrá y no tendrá freno que le detenga", sostenía el letrado, logrando ablandar así la voluntad de los magistrados de la Corte, quienes confirmaron la sentencia del juez inferior, tal y como pedía Montes de Oca. ${ }^{65}$

Ante casos de violencia sexual, los abogados defensores también recurrieron a la edad para clamar mayor indulgencia para sus defendidos. Así, según el abogado Manuel Zea, daba igual que su defendido, José María Leiva, fuera culpable de haber tratado de estuprar a una niña de seis años, pues, aun en el supuesto de que el delito estuviera plenamente justificado, lo disculpaban sus quince años de edad. El haber tratado de violar a la menor constituía ante los ojos del defensor

\footnotetext{
61 Compurgar es un término jurídico que hace referencia al pago o cumplimiento de la pena o sanción impuesta.

62 AGNM, TSJDF, 1834, caja 94, exp. 48, “Toca a la causa de Antonio Bulches y María Olivera por incesto", s/f.

63 Juan Bautista Morales fue abogado, escritor, diputado por Guanajuato en el congreso Extraordinario de 1824 y fiscal de la Suprema Corte de Justicia, máxima instancia judicial a nivel federal. Para un mayor estudio de su actuación como fiscal ante delitos sexuales durante la primera mitad del siglo XIX véase (Palafox, 2017).

64 AGNM, TSJDF, 1834, caja 94, exp. 48, “Toca a la causa de Antonio Bulches..., s/f.

65 AGNM, TSJDF, 1834, caja 94, exp. 48, “Toca a la causa de Antonio Bulches..., s/f.
} 
"un retozo tan común y propio de la edad de ambos" que no ameritaba castigo. ${ }^{66}$

La edad de la víctima fue también determinante a la hora de tipificar un delito de estupro ya que, en caso de ser perpetrado contra una joven que no alcanzara la pubertad, la doctrina lo clasificaba de "inmaturo" y ameritaba, por ello, mayor condena (De la Pascua, 2010: 36 y 109 y Escriche, 1852: 654). Mantener relaciones sexuales con una niña era como querer "coger la temprana flor" sin ser "llegada la primavera", según la metáfora elaborada por el licenciado Mariano Urruchi ${ }^{67}$. Los juristas parecían coincidir aquí en que las jóvenes no viripotentes, es decir, que no alcanzaran la madurez suficiente para poder contraer una "unión legítima” y "contribuir a la propagación de la especie", según el abogado carecían de deseo, por lo que no podían ser sospechosas de tener ninguna responsabilidad ante un delito sexual ${ }^{68}$.

¿Cuál era la edad que determinaba el paso de una mujer a la pubertad? Según el propio Urruchi, esto no podía determinarse con exactitud y, como quedó recogido en el Derecho canónico, si una mujer alcanzaba la pubertad antes de cumplir los doce años podía contraer válidamente matrimonio al suplir la edad con "la malicia" demostrada. ${ }^{69}$ En atención a la conocida como "teorías de los climas" de Georges Louis Leclerc, conde de Buffon, una de las principales variables a la hora de establecer la viripotencia de una joven era su origen geográfico. Recordando las palabras de este "célebre naturalista", retomadas por los principales tratadistas europeos de Derecho forense como el francés Foderé, el letrado Urruchi afirmaba que existían regiones en la tierra donde la naturaleza despertaba más tempranamente y todos los periodos de la vida se adelantaban con una velocidad prodigiosa (Foderé, 1801: 108): "En muchas partes de África es tan anticipada la propensión a unirse los dos sexos que las más de aquellas mujeres no hacen memoria de la época en que dejaron de ser vírgenes". ${ }^{70}$ De la misma forma, en los climas ardientes de Asia, África y América, según este abogado, las mujeres entraban en la

\footnotetext{
66 AGNM, TSJDF, 1846, caja 209, exp. 32, “Diligencias de sumaria instruidas..., f. 14v.

67 AGNM, TSJDF, 1846, caja 209, exp. 32, “Diligencias de sumaria instruidas..., f. 14v.

68 AGNM, TSJDF, 1846, caja 209, exp. 32, “Diligencias de sumaria instruidas..., f. 14v.

69 AGNM, TSJDF, 1830, caja 58, exp. 78, "Expediente supletorio del formado contra D. Juan Fenzi por estupro", s/f.

70 AGNM, TSJDF, 1830, caja 58, exp. 78, “Expediente supletorio...”, s/f.
} 
pubertad a los 10 años y aun a los 9, y "reconociendo esta verdad", era una injusticia castigar como inmaturo el estupro de una mujer menor de los doce años" en un "país caliente" como México, en el que todos admiraban "la precocidad de las facultades morales y físicas"." De esta forma, Urruchi trataba de justificar que el estupro inmaturo, cometido por su cliente sobre la joven Reinosa de once años, no era tal sino un "desliz propio de la flaqueza humana", habido con una mujer de "malicia suficiente para suplir la edad"72

Pertenecer a los estratos populares de la sociedad fue otro de los atenuantes más recurridos a la hora de defender a un reo. La abismal diferencia cultural que atravesó la desigualdad imperante en la capital mexicana durante todo el siglo XIX, creó entre la elite diversos estereotipos y actitudes despreciativas ante el grueso de la población, dibujada como una gran masa desconocedora de sus propias leyes. Por ejemplo, frente a ilícitos sexuales comúnmente aceptados "entre el pueblo", como el incesto, según se lamentaba el letrado Luis Gonzaga Mena, los acusados eran castigados "sin saber por qué", siendo conscientes del cargo que se les hacía sólo "a trueque de pasar unos días o unos años oprimidos en un grillete" ${ }^{73}$

A pesar de la formal abolición de las diferencias jurídicas por motivos raciales, establecida desde inicios de la independencia del país, ${ }^{74}$ en la práctica, los indígenas siguieron conformando, ante los ojos de esta elite, una otredad asociada a los sectores marginados de la población. ${ }^{75}$ Esta situación fue aprovechada por los letrados a la hora de

\footnotetext{
$71 \quad$ AGNM, TSJDF, 1830, caja 58, exp. 78, “Expediente supletorio...", s/f.

AGNM, TSJDF, 1830, caja 58, exp. 78, "Expediente supletorio..., s/f.

AGNM, TSJDF, 1842, caja 177, “Contra Bartolo Velázquez y Josefa Negrete por incesto y deserción de tropas el primero", f. 26v.

${ }_{74}$ En 1822 fue ratificada legalmente la igualdad jurídica de todos los mexicanos sin distinción étnica, reconocida un año antes en el "Plan de Iguala", en el que se abolieron las distinciones jurídicas por criterios étnicos, afirmando que todos los habitantes del Imperio, "sin otra distinción que su mérito y virtudes", eran ciudadanos idóneos para optar a cualquier empleo. "Proclama en la cual va inserto el Plan de Independencia de que se ha hecho mención" (Montiel, 1871: 47). Septiembre 17 de 1822. "Se prohíbe clasificar a los ciudadanos mexicanos por su origen”, en Dublán y Lozano, 1876: 628-629.

75 El proyecto decimonónico de nación, imperante entre la intelectualidad liberal mexicana, fue un proyecto asimilador, que implicaba la eliminación de las identidades étnico-nacionales del país. La integración de un ensalzado pasado prehispánico en su articulación contrastó con el fuerte desprecio hacia el indígena contemporáneo, considerado un lastre para los conceptos de "progreso" y "civilización" defendidos en dicho proyecto. Véase López, 2001: 44-45; Sanz, 2010: 83-118, y Urías, 2000: 106-113.
} 
solicitar un trato más indulgente por parte de la autoridad judicial, contribuyendo con ello a reforzar la distorsionada imagen del indio ignorante, conceptualizado como un vestigio del corrompido sistema colonial que había que erradicar mediante la asimilación de los indígenas en el proyecto nacional de modernización estatal. Así, una "mujer muy joven, india y extremamente ignorante puesto que no sabe ni hablar", según el abogado Agustín Guiol, reunía todos los requisitos que la eximían de ser condenada por la justicia por un delito de incesto. ${ }^{76}$

“¿Cómo podrá negarse que conforme es mejor la educación del delincuente es mayor su delito? ¿Quién comete mayor transgresión, el soldado raso que engrosa las filas de los facciosos o el oficial que lo seduce y hace prevaricar? Sin duda que el segundo pues el oficial tiene más civilización, más cultura, en otra palabra, el oficial tiene más educación y más principios para conocer la enormidad del delito que va a cometer".77

Con este alegato el letrado Montes de Oca trataba de justificar que el incesto cometido por sus defendidos debía perdonarse por su ignorancia, al pertenecer a la esfera "más baja del pueblo"78 El desconocimiento de las penas, según esta tendencia jurídica, dispensaba de infringirlas en consideración de un principio de equidad, pues, como argumentaba el letrado Marcos Hernández, no era buena justicia la que no se mezclaba con la misericordia. ${ }^{79}$

Esta misma lógica argumentativa trasladada a un caso de violencia sexual podía llevar a estrambóticas reflexiones, como las elaborados por el abogado de pobres Francisco Mariscal quien, en su defensa de Bonifacio Ramírez, acusado de haber querido forzar a una doncella de diecisiete años, alegó lo siguiente:

"Es cierto que la gente del pueblo que no tiene la educación de la gente más acomodada, acostumbran retozar o jugar de manos aun

\footnotetext{
${ }_{76}$ Agustín Guiol en la defensa de Ramona Pérez. AGNM, TSJDF, 1837, caja 119, exp. 23, “Toca a la causa de José Trinidad García y Ramona Pérez por incesto", f. 24v.

AGNM, TSJDF, 1831, caja 65, exp. 33, "Luis Islas e Hilaria Ramírez por incontinencia incestuosa", 3v.

78 AGNM, TSJDF, 1831, caja 65, exp. 33, “Luis Islas e Hilaria Ramírez..., f. 3v.

79 Marcos Hernández en defensa de los indígenas Bernabé Antonio y María Hilaria acusados de estupro e incesto. AGNM, TSJDF, 1843, caja 193, "Contra Bernabé Antonio y María Hilaria por estupro e incesto", f. 11r.
} 
entre personas de diversos sexos al grado de muchas veces creerse que o están peleando o tienen otras intenciones y esto es tan notorio que creo que no hay persona que no lo haya presenciado alguna vez. Las relaciones que se supone hay entre Ramírez y Casimira arguyen más para creer que fue un simple juguete pues personas que han dormido muchas veces en un mismo cuarto es de creerse que tienen alguna estrechez".

La "crasa ignorancia", "estupidez y falta de educación" de algunos acusados, ${ }^{81}$ así como la natural inocencia y debilidad femenina, fueron presentadas por estos letrados como evidentes circunstancias atenuantes, al hallarse "destituidos enteramente de aquella educación que es indispensable para observar lo que es justo, y apartarse de todo mal".82 Este discurso estuvo impregnado de una condescendencia que operó como un arma de doble filo, pues, si el déficit cultural de estos sectores sociales -más de la mitad de la población en el caso de las mujeres- los hacía incapaces de reconocer el carácter delictivo de sus acciones, lejos estaban de poder integrar las filas de la ciudadanía activa, por lo que, siguiendo esta lógica argumentativa, su sujeción política parecía seguir siendo más que necesaria.

\section{Conclusiones}

A lo largo del siglo XIX, de acuerdo con las reglas del sistema penal, los abogados representaron, es decir, hablaron por las distintas partes enfrentadas en un juicio. En cierta medida, operaron como traductores de los intereses de los litigantes, a través de códigos comunicativos propios del foro. Fungieron, de esta manera, como filtros necesarios con los que las personas comunes, y por ende, desconocedoras de las reglas del juego judicial, debían contar si pretendían ganar un proceso criminal. Mediante la exposición de distintos elementos probatorios, como los testimonios fehacientes de testigos y otros, los abogados dis-

\footnotetext{
80 AGNM, TSJDF, 1855, caja 307, “Contra Bonifacio Ramírez por conato de forzamiento", ff. $13 \mathrm{v}-14 \mathrm{r}$.

${ }^{81}$ Expresiones referidas por el licenciado Joaquín Velasco en AGNM, TSJDF, 1841, caja 160, "Estupro", f. 13v. El uso del calificativo "estúpido" fue frecuente entre abogados para aludir a la escasa capacidad de razonamiento de sus defendidos.

${ }_{82}$ Razonamiento expuesto por el defensor Clemente Vélez en el juicio contra de Isidro Gutiérrez y María Inés Candelas acusados de incesto. AGNM, TSJDF, caja 151, 1840, exp. 26, “Toca a la causa contra Isidro Gutiérrez y María Inés Candelas por incesto", s/f.
} 
cutieron, en la práctica, sobre las condiciones y el grado de honradez de los procesados, víctimas y victimarios. Estos, en la mayor parte de los casos, tras haber sido llamados a declarar, esperaron entre las paredes de la cárcel o de su respectivo domicilio las noticias que el letrado correspondiente les iba dando sobre su futuro, permaneciendo, de esta manera, ajenos a su propia historia.

Gracias al análisis de las defensas formuladas, hemos constatado cómo los letrados recurrieron a la persuasión como principal arma en su oratoria. Al respecto, aprovechando la caída en desuso de la normativa vigente, la casuística y a las circunstancias que rodeaban la comisión delictiva, junto con su elocuencia, relegaron a las leyes a una posición secundaria en sus discursos.

De esta manera, mientras que la legalidad sirvió para tratar de deslegitimar las acusaciones femeninas en los procesos de adulterio, diversos estereotipos de género, compartidos con las autoridades judiciales, lo hicieron para tratar de invalidar los relatos de mujeres, ya fueran acusadoras, víctimas o testigos. Tener un comportamiento sexual al margen de los parámetros de pudor y castidad debidos o, simplemente, ser mujer, fueron algunos de los argumentos más empleados para desacreditarlas. Así, mientras que las mujeres fueron tachadas de seres carentes de deseo carnal -a no ser que estuviesen viciadas- e incapaces, por su naturaleza, para desempeñar actividades o cargos que implicaran responsabilidad, incluyendo el ejercicio de la ciudadanía, la única incapacidad masculina comúnmente aceptada en el ámbito jurídico fue la de controlar sus impulsos sexuales antes supuestas provocaciones femeninas.

Por otro lado, la asociación de los sectores populares y de la población indígena con la ignorancia en estos alegatos, dentro de un desprecio generalizado entre las elites hacia los grupos referidos, evidenció la distancia socioétnica que, tanto en un nivel simbólico como material, existía entre el grueso de la población y los encargados de representarlos ante la justicia. Dentro de esta misma lógica discursiva, el desprecio se tornaba en condescendencia en función de los intereses de los letrados. Así, el género, la edad o la condición socioeconómica operaron también como variables a la hora de construir discursos eximentes de la responsabilidad penal de los acusados. 
El análisis de estas estrategias defensivas, interpretadas como parte de una cultura jurídica compartida, nos ha permitido apreciar una complicidad entre la elite, subyacente a los discursos esgrimidos. El abogado correspondiente buscaba convencer a miembros de su mismo estatus social. Si bien los jueces ocuparon un lugar más elevado que los abogados, dentro la jerarquía jurídica ambos gozaron de un capital simbólico notoriamente superior que el de la mayoría de los actores o procesados por delitos de índole sexual. El empleo de los letrados en sus discursos de conceptos inclusivos en apariencia, como "público", "todos" o "nosotros", consideramos que no aludieron a la sociedad real, sino a un proyecto social deseado, a un conjunto identitario restringido y a un código comunicativo, en general, y de valores, en particular, compartido por esta minoría.

Advertimos, así, una cultura jurídica situada al margen de las leyes vigentes, de acuerdo con los nuevos principios liberales, pero que, al tiempo, mantuvo la pervivencia de valores de Antiguo Régimen, dentro de una dinámica que contradecía el principio liberal de una misma pena para un mismo delito y que abogaba por aplicar criterios resolutivos en función de las particularidades de cada implicado en la acción delictiva. La reproducción desde estas esferas de poder, al respecto, de un código de valores basado en la calidad de las personas, acorde con prejuicios sociales de diversa índole y de un modelo organizativo basado en la separación de los espacios público y privado -en función del género, la clase y la etnia- contribuyó a consolidar un sistema sociopolítico ampliamente desigual, que caracterizó a las instituciones capitalinas a lo largo de la centuria.

\section{Referencias bibliográficas}

\section{Fuentes primarias}

\section{a) Fondos Documentales}

Fondo Tribunal Superior de Justicia del Distrito Federal. Archivo General de la Nación, México, 1827-1871.

\section{b) Impresos y publicaciones oficiales}

De la Pascua, A. (2010). Febrero Mejicano o sea la Librería de Jueces, abogados y escribanos que, refundida, ordenada bajo nuevo 
método, adicionada con varios tratados y con el título de $\mathrm{Fe}$ brero Novísimo dio a luz D. Eugenio de Tapia. Nuevamente adicionada con otros diversos tratados y las disposiciones del Derecho de Indias y del Patrio, por el Lic. Anastasio de la Pascua. México: Suprema Corte de Justicia de la Nación, (1 $1^{a}$ edición, 1835).

De la Peña y Peña, M. (1835). Lecciones de práctica forense mejicana escritas a beneficio de la Academia Nacional de derecho público y privado de Méjico. México: Juan Ojeda.

Dublán, M. y J. M. Lozano (1876). Legislación mexicana ó colección completa de las disposiciones legislativas expendidas desde la Independencia de la República. México: Imprenta del Comercio.

Dublán, M. y L. Méndez (1870). Novísimo Sala mexicano o ilustración al derecho real de España con las notas del Sr. Lic. D. J. M. de Lacunza. Edición corregida y considerablemente aumentada con nuevas anotaciones y refundiciones, relativas a las reformas que ha tenido la legislación de México hasta el año de 1870, por lo señores don Manuel Dublán y don Luis Méndez, abogados de los tribunales de la República. México: Imprenta del Comercio de N. Chávez.

Escriche, J. (1852). Diccionario razonado de legislación y jurisprudencia. Nueva Edición corregida notablemente y aumentada con nuevos artículos, notas y adiciones sobre el derecho americano, por Don Juan B. Guim. París: Librería de la Rosa, Bouret y Cía.

Foderé, F. (1801). Las leyes ilustradas por las ciencias físicas o tratado de medicina legal y de higiene pública escrito en francés por el ciudadano Francisco Manuel Foderé, médico del Hospital de caridad de la ciudad de Marsella. Madrid: Imprenta de la Administración del Real arbitrio de Beneficencia.

Montiel y Duarte, I. (1857). Derecho público mexicano. México: Imprenta del Gobierno.

Morales, J. B. (1857). El Gallo Pitagórico. Colección de artículos críticopolíticos y de costumbres. México: Ignacio Cumplido.

Rodríguez de San Miguel, J. (1852). Pandectas Hispano-Megicanas, o sea Código General comprensivo de las leyes generales, útiles y vivas de las siete Partidas, Recopilación Novísima, la de Indias, autos y providencias conocidas por de Montemayor y 
Beleña, y cédulas posteriores hasta el año de 1820. México: Mariano Galván Rivera.

Vilanova y Mañes, S. (1827). Materia Criminal forense o Tratado Universal teórico y práctico de los delitos y delincuentes en género y especie para la segura y conforme expedición de las causas de esta naturaleza. París: Librería Hispano-Francesa de Rosa, (1ª edición, 1807).

\section{Fuentes secundarias}

\section{a) Artículos y capítulos de libros}

Antaki, C. y S. Condor (2000). “Cognición Social y Discurso", en T. A. Van Dijk (coord.). El discurso como estructura y proceso. Barcelona: Gedisa, pp. 453-489.

Bailón Vásquez, F. (2008). "Las garantías individuales frente a los derechos sociales: una discusión porfiriana en torno a la prostitución", en J. Tuñón (compiladora). Enjaular los cuerpos. Normativas decimonónicas y feminidad en México. México: COLMEX, pp. 327-376.

Baraona González, J. (2010). "La cultura jurídica chilena: apuntes históricos, tendencias y desafíos", en Revista de Derecho, №35, pp. 427-448.

Cabrera, M. Á. (2003). "La crisis de la historia social y el surgimiento de una historia postsocial”, en Ayer, №51, pp. 201-224.

Carner, F. (1987). “Estereotipos femeninos en el siglo XIX”, en C. Ramos Escandón (coord.). Presencia y Transparencia. La mujer en la Historia de México. México: COLMEX, pp. 95-109.

Carrillo, A. M. (1999). "Nacimiento y muerte de una profesión. Las parteras tituladas en México”, en DYNAMIS, N¹9, pp. 167-190.

Gálvez Ruiz, M. Á. (2012). “La construcción del nuevo Estado y la cuestión de las mujeres en México", en Chronica Nova, N³8, pp. 125-150.

López Sánchez, O. (2001). “La mirada médica y la mujer indígena en el siglo XIX", en Ciencias, N60, pp. 44-49.

Núñez Rebolledo, L. (2010). "Nacionalidad y mujeres en las constituciones de México", en Versión, N²5, pp. 165-179.

Ortiz Leroux, J. (2007). "El sujeto de la ciudadanía en la constitución mexicana", en Revista del Posgrado en Derecho de la UNAM, N5, pp. 319-334. 
Ovalle Favela, J. (1981). "Los antecedentes del jurado popular en México", en Criminalia, N7-9, pp. 61-94.

Padilla Arrollo, A. (2000). "Los jurados populares en la administración de justicia en México en el siglo XIX”, en Secuencia, N47, pp. 137-169.

Palafox Menegazzi, A. (2017). “Justicia, matrimonio y civilización en la primera mitad del siglo XIX mexicano: una aproximación a través de la figura del fiscal Juan Bautista Morales", en A. García, R. Tribaldos y M. García (eds.). Economía, política y sociedad en Iberoamérica (siglos XVI-XIX) Actuales líneas de investigación histórica. Alicante: Universidad de Alicante, pp. 127-146.

Palafox Menegazzi, A. (2017a). “Tutela y desposesión corporal ante casos de estupro, rapto y violación en la ciudad de México del siglo XIX", en O. Ursache (coord.). Cuerpos que hablan. Estudios interdisciplinarios de cuerpología femenina. Turku: Turun Yliopisto, pp. 187-204.

Palafox Menegazzi, A. (2013). "Justicia, regulación sexual y feminidad en la ciudad de México (1827-1870)", en Trashumante. Revista Americana de Historial Social, №2, pp. 8-3.

Ramos Escandón, C. (2006). "Trabajo e identidad femenina en México: el ejemplo del textil, tabaco y trato sexual", en G. GómezFerrer y G. Cano (coords.). Historia de las Mujeres en España y América Latina: Vol. 3. Del siglo XIX a los umbrales del XX. Madrid: Cátedra, pp. 799-813.

Ramos Escandón, C. (2004). “Legislación y representación de género en la nación mexicana", en S. Pérez y P. Ravelo (coords.). Voces disidentes. Debates contemporáneos en los estudios de género en México. México: CIESAS, Miguel Ángel Porrúa, pp. 93-112.

Ramos Escandón, C. (1987). “Señoritas porfirianas: mujer e ideología en el México progresista, 1880-1910", en C. Ramos Escandón. (coord.). Presencia y Transparencia. La mujer en la Historia de México. México: COLMEX, pp. 145-162.

Rubin, G. (1986), "El tráfico de mujeres: notas sobre la economía política del sexo", en Nueva Antropología, Vol. VIII, N³0, pp. 95145 ( $1^{a}$ edición en inglés, 1975).

Sánchez-Arcilla Bernal, J. (2013). “La delincuencia femenina en México a fines del siglo XVIII", en Cuadernos de Historia del Derecho, $\mathrm{N}^{\circ} 20$, pp. 89-154. 
Sanz Jara, E. (2010). “Continuidades en el discurso intelectual y político mexicano sobre los indígenas, siglos XIX y XX", en Tzintzun, Revista de Estudios Históricos, N51, pp. 83-118.

Speckman Guerra, E. (2015). "La justicia. Cádiz y la experiencia mexicana”, en México en Cádiz, 200 años después. Libertades y democracia en el constitucionalismo contemporáneo, México: Tribunal Electoral del Poder Judicial de la Federación, pp. 43-59.

Speckman Guerra, E. (2007). "Justicia, revolución y proceso. Instituciones judiciales en el distrito Federal (1810-1929)", en A. Mayer. (coord.). México en tres momentos: 1810-1910-2010. México: UNAM, pp. 189-206.

Speckman Guerra, E. (2006). "Los jueces, el honor y la muerte. Un análisis de la justicia (Ciudad de México. 1871-1931)”, en Historia Mexicana, ํ4, pp. 1411-1466.

Speckman Guerra, E. (2005). "El jurado popular para delitos comunes: leyes, ideas y prácticas (1869-1929), en S. Cárdenas. Historia de la Justicia en México, siglos XIX y XX, México: Suprema Corte de Justicia de la Nación, pp. 743-787.

Van Dijk, T. A. (2000). "El estudio del discurso", en T. A. Van Dijk, $E l$ discurso como estructura y proceso. Barcelona: Gedisa, pp. 21-65.

Velázquez Delgado, G. (2008). "La ciudadanía en las constituciones mexicanas del siglo XIX: inclusión y exclusión político-social en la democracia mexicana", en Acta Universitaria, vol. XVIII, Nº 1 , pp. 41-49.

\section{b) Libros}

Arendt, H. (2009). La condición humana. Buenos Aires: Paidós.

Berrueco García, A. (2006). Veinticinco forjadores de la tradición jurídica mexicana. México: UNAM.

Bourdieu, P. (2000). La dominación masculina. Barcelona: Anagrama.

Núñez Becerra, F. (2002). La prostitución y su represión en la ciudad de México (siglo XIX): prácticas y representaciones. Barcelona: Gedisa.

Radkau, V. (1994). Mujeres y médicos en el México decimonónico. De imágenes y espacio. México: CIESAS.

Scott, J. (2000). Los dominados y el arte de la resistencia. Discursos ocultos. México: Ediciones Era. 
Tomás y Valiente, F. (1969). El derecho penal de la monarquía absoluta: siglos XVI-XVII-XVII. Madrid: Editorial Tecnos.

Tunón, J. (1991). El álbum de la mujer: antología ilustrada de las mexicanas. El siglo XIX (1821-1880). México: INAH.

Urías Horcasitas, B. (2000). Indígena y criminal. Interpretaciones del derecho y la antropología en México, 1871-1921. México: Universidad Iberoamericana. 